\title{
Family Disorganization of Konon Poetry in A Collection of Poems Perihal Gendis by Sapardi Djoko Damono (Study of Social and Ecocritism)
}

\author{
Anindita Fikri Amalia ${ }^{1 *}$, Redyanto Noor ${ }^{2}$ \\ ${ }^{1}$ Master of Literature, Diponegoro University, Semarang, Indonesia \\ ${ }^{2}$ Master of Literature, Diponegoro University, Semarang, Indonesia
}

\begin{abstract}
This research aims to describe, mention, and analyze the family disorganization in Konon poetry by Sapardi Djoko Damono. This research uses the library research method with the object of the study of Konon poetry and uses a sociological, literary approach. This research represents family disorganization in the Konon poetry by Sapardi Djoko Damono was caused by several reasons. Based on these causes, family disorganization has resulted in an imbalance of roles in the family, which will impact affection for children. Furthermore, there was found discovered the reasons for her family disorganization there are divorce, infidelity, and lack of good communication between family members.
\end{abstract}

\section{Introducing}

As the smallest organization in society, the family has a useful capacity and role for maintaining family harmony. Murdock (in Abustam) [1]. Defined family as a social group characterized by common residence, economic cooperation, and reproduction. It includes adults of both sexes, at least two of whom maintain a socially approved sexual relationship, and one or more children, own or adopted, of socially cohabiting adults. However, if one of the members does not do his role properly, the family will be in chaos, or there will be family disorganization. Family disorganization is caused by several reasons, such as lack of communication, divorce, and separation due to mental disorders. Based on these causes, family disorganization results in an imbalance of roles in the family.

This study analyzes the family disorganization found in Konon [2] poetry by Sapardi Djoko Damono. The theoretical object presented is family disorganization, a basis used to analyze the irregularity of family relationships in Konon poetry written by Sapardi Djoko Damono. In this research, the writer chooses Konon poetry contained in a collection of poems Perihal Gendis by Sapardi Djoko Damono as a material object. The girl's loneliness impacts the occurrence of disorganization in her family. It will have an impact on her psychological and social life because she is currently growing. Therefore, the writer chose the sociology of literature and ecocriticism theory to reveal family disorganization in Konon poetry.

* Corresponding author: fikriamaliaa@gmail.com 
Some of the previous study of this research has been carried out by Mohammad Tri Syafaan (2021) entitled "Masalah Kejiwaan Tokoh Utama dalam Prosa Liris Perihal Gendis Karya Sapardi Djoko Damono", Teguh Supriayanto (2020) entitled “The Imagery In Perihal Gendis Poetry Book By Sapardi Djoko Damono and Its Application as Drilling Material For Literature Learning in High School", L. Sholihah (2019) entitled "Puitika Kesepian dalam Perihal Gendis Karya Sapardi Djoko Damono".

\section{Problem Formulation}

This research tries to answer a question related to the results of the analysis of Konon poem by Sapardi Djoko Damono and the family disorganization that is contained in it with a sociological study of literature.

\section{Theory}

\subsection{Sociology of Literature}

Ratna [3] defined the sociology of literature as an interdisciplinary science used to analyze literature concerning society. From this definition, the sociology of literature used in this study refers to the social relationships or values in literary works with their environment, especially the relationship in family sociology. The sociology of literature is divided into ten aspects, language, religion, philosophy, politics, history, psychology, sociology, culture, ethnology, and other branches of art. In this research, the writer uses the sociological literature theory, which concentrates on family disorganization on Konon poetry by Sapardi Djoko Damono.

\section{a. Family Disorganization}

Murdock (in Abustam) defined a family as a social group characterized by typical residence, economic cooperation, and reproduction. It includes adults of both sexes, at least two of whom maintain a socially approved sexual relationship, and one or more children, own or adopted, of socially cohabiting adults. Family disorganization is the breakdown of the family as a unit because its members fail to fulfil their obligations by their social roles (Soekanto) [4].

Goode [5] explained family disorganization as the break-up of a family unit, the dissolution or fracture of a structure of social roles when one or more members fail to perform their role obligations adequately. Equating marital instability with disorganization, Goode has pointed out that unstable families are problem-ridden and see divorce as a "publicly recognized form of marital instability". If an individual has family disorganization, it would be the subject of gossip from the general public because they are considered to have several negative things that have chaos in their family. The forms of family disorganization, according to Goode [6], include:

a. Illegality

Is a situation when a father or husband is not there and cannot doing his role as it should be.

b. Cancellation, separation, divorce, and leaving

Due to the act of leaving each other by one of the couples and stop doing their role commitments. 
c. Blank family

Is a condition when a family lives together in one place but does not greet or interact and fails to provide emotion to each other. In other words, there is no good communication between family members.

d. The absence of a person from a partner due to undesirable someone is circumstances

Situation when abandoned partner because of death, imprisonment, or separation due to war, depression, or another calamity due to undesirable things.

\section{b. Ecocritism Theory}

Ecocritic is a theory that tries to evaluate contemporary texts and culture which serves to represent the environment which is a response to the crisis that occurs in the environment because ecocritic asks several questions on the relationship between environment and literature, the ecocritical theory deals with ecology. Ecocritic is offering an ecological interpretation of a text.

Glotfelty [7] defined that ecocriticism as the study of the relationship between literature and the physical environment. Just as feminist criticism examines language and literature from a gender-conscious perspective and Marxist criticism brings an awareness of modes of production and economic class to its reading of texts, ecocriticism takes an earth-centered approach to literary studies.

Ecocriticism [8] used an important tool to interpreting the relationship between literature and the environment. Ecocriticism is not only emphasizing the 'harmony' of humanity and nature but also talks about the destruction caused to nature by the changes which take place in the modern world for most of which man is directly responsible.

\section{Discussion}

\section{a. Descriptions of Family Disorganization in the Konon poem}

In the first part of the first line of Konon's poem, imagine that the girl hopes that her parents give her love and attention every day. However, the girl did not get it because her parents were busy with their lives. They left their child alone in her loneliness indirectly. In the second line, diction tetapi ada sebilah pisau / di sebelahmu, means there is no happiness for her. The diction sebilah pisau is meant her parents kill her slowly with the loneliness. And then, in the second line, it is described that the love from her parents makes her uncomfortable, and she feels like a stranger if they are together. The diction tetapi jeruk akan dibelah dua means that the love that should only be for the girl is shared with the new family members who are rivals for the attention and love of her parents.

In the third part, it is explained that her parents are separated or divorced. The diction in this part means that one of her parents is tired of leading a life. They decided to separate and stop doing their commitments in the family. This impacts the imbalance of social roles in her family, and it makes the girl not getting love from their parents.

Moreover, the fourth part of this poem further explains that her family's life is no longer harmonious. The diction of naga penjaga is interpreted as a father who gives comfort and protection for safeguarding is losing her alone. This will make the girl feels as if her parents are no longer love her.

Furthermore, the fourth part of the Konon poem is the same as the previous parts. This part means that the girl feels no one loves her anymore because their parents got a divorce. This situation is relevant to the children who had divorced parents. They feel worthless and 
think that no one loves them anymore because their parents left them alone. That can be reflected in the girl's family life because of the selfishness and lack of communication.

\section{b. Family Disorganization in Konon Poem}

Based on the description of Konon poem by Sapardi Djoko Damono, it can be seen that the girl's family life is significantly related to living today, it is because the parents who have selfishness and lack communication, so they think if divorce is a good choice. However, it makes their family had family disorganization. After that, their child will impact, and they will feel if their parents do not love her anymore and feel worthless. However, honestly, the family, as the smallest part of society, should have the ability to makes the members feel comfortable and get full of love. If the function of each family member is not filled, there will be chaos, and if they keep silent as everything has been finished without any reconciliation, one day it will be divided. The function of protecting among family members is not filled. Sooner or later, it will be doing disorganization in the family. As seen in the third part of the first line, when one of the family members feels bored with their relationship, they choose to give up and become selfish.

However, in Konon poem, based on the description of the poem above, the girl is no longer getting love, protection, and sympathy from her family. The functions that should exist and be a balance in family life are not fulfilled in her life. That means her family is in on disorganization. As mentioned before, if there is neither communication, dishonesty between family members, arguments, or infidelity in the family, that will threaten family harmony. The effect of family disorganization that occurs to the girl is that she will think if no one loves her anymore and feels worthless because her parents leave her alone.

From the diction in Konon poem in the third part, the disappearance of naga penjaga, which is represented as a father, causes his role to give love and protection to the family to be lost, making the girl feel no one care about her anymore. It is family disorganization caused by separation and divorce. Her father is cheating, and its make disorganization in her family. That makes the girl feel discomfort if they are at the same place.

[9] The family disorganization by the girl is also significantly related to life today. [10] Based on several reports, the divorce rate during a pandemic like this increases compared to before the pandemic. This can be used as the reason that the level of family harmony and the carrying out of family functions are deficient. This happens because the economic income in the family decreases, there will be disputes, dishonesty in the family, this will affect the establishment of good communication between family members. Causing dishonesty between members, it ended up being a divorce. It is explained in the description in the first verse of the fourth part on diction dan ingin menjadi telor / yang lonjong dan halus; this diction indicates that her family's life is no longer harmonious because there is no good communication between family members, causing family disorganization.

\section{Conclusion}

Konon poem by Sapardi Djoko Damono is a long poem consisting of four parts. Depiction of family disorganization in Konon's poem can be seen from the diction used by the author. In the lines written by the author, it is revealed that the girl feels worthless because of her parent's divorce. In the depiction of diction in this poem, it is stated that the parents who should give the girl comfort and love are no longer received because the harmonious family that gave them protection was divided and disorganized.

Family disorganization in the girl's family happens due to divorce, family in an empty membrane, infidelity. These things can be seen in the diction written by the writer in the poem Konon. In addition, Konon poem is also relevant to life today. Family disorganization 
at this time has increased compared to life before the pandemic. The divorce rate is currently on the rise, meaning that many families are feeling chaos due to factors resulting in family disorganization.

\section{References}

1. Abustam, M. Idrus, Perubahan Struktur Keluarga dan Pengembangan Pendidikan Anak dalam Keluarga serta Implikasi Kebijaksanaan, in Seminar dan Kongres Nasional I Ikatan Sosiologi Indonesia, 7-9 December 1991, Bandung, Jawa Barat (1991)

2. S. D. Damono, Perihal Gendis, (Gramedia Pustaka Utama Jakarta, 2018)

3. N. K. Ratna, Teori, Metode, dan Teknik Penelitian Sastra, (Pustaka Pelajar Yogjakarta, 2004)

4. S. Soekanto, Sosiologi Suatu Pengantar, (PT Raja Grafindo Persada Jakarta, 1994)

5. W. J. Goode, Sosiologi Keluarga. (Bumi Aksara Jakarta, 1991)

6. W. J. Goode, Sosiologi Keluarga. (Bumi Aksara Jakarta, 1991)

7. C. Glotfelty, H. Fromm. ed., The Ecocriticism Reader: Landmarks in Literary Ecology, (University of Georgia press Athens and London, 1996)

8. V. Fenn, JOELL, 2(2), (2015)

9. A. Tristanto, Sosio Informa Kajian Permasalahan Sosial dan Usaha Kesejahteraan Sosial, 6(3), (2020)

10. U. T. Wijayanti, Jurnal Ilmu Keluarga dan Konsumen, 14(1), (2021) 